\title{
THE EFFECT OF PANCREATIN THERAPY ON FAT ABSORPTION AND NITROGEN RETENTION IN CHILDREN WITH FIBROCYSTIC DISEASE OF THE PANCREAS
}

BY

\author{
RUTH HARRIS, A. P. NORMAN and W. W. PAYNE \\ From The Hospital for Sick Children, Great Ormond Street, London
}

(RECEIVED FOR PUBLICATION JUNE 8, 1955)

For many years substitution therapy with various preparations of the pancreas has been given to children with fibrocystic disease of the pancreas as a routine treatment. This is recommended in most textbooks of paediatrics (Rapoport, 1954; Norman, 1954), although the practice has been based on the clinical evaluation of the results rather than on any objective study of the results of metabolic balances. May (1954) claimed that better results were obtained by the administration of a generous high-protein diet without pancreatin, which he believes impairs the appetite.

The study was undertaken in order to find out, by means of metabolic balances, what effect pancreatin replacement therapy does in fact have on fat and nitrogen absorption and retention.

\section{Selection of Cases}

The children studied had all been under observation for some years and clinically appeared typical cases of fibrocystic disease. In every case but one (Case 11, L.B.) examination of the duodenal juice had been satisfactorily carried out and had shown complete absence of trypsin, and in those cases in which the enzyme estimation had been done, absence of lipase and amylase. It was essential for the purpose of the balance that the children should be continent of urine and faeces and be able to cooperate, so only children between the ages of 4 and 10 were chosen, but no special selection was made as regards sex or severity of the disease.

A few minor disturbances of health occurred among the children during the long study period and four suffered from respiratory infections requiring chemotherapy. Only one child proved such an unsatisfactory subject that the study had to be abandoned in her case.

\section{Method}

On each child three sets of balances were carried out, giving first no pancreatin, then 5 and $15 \mathrm{~g}$. The order in which the balances were done was varied from case to case in order to use all six possible variations. The pancreatin was given four times daily immediately before meals, and was usually swallowed dry or stirred into a little cold milk or water. The pancreatin used was the usual hospital preparation of powdered pancreatin (B.P. triple strength) treated to form enteric-coated granules (Bodian, 1952; Norman, 1954). The nitrogen content of the pancreatin so prepared was repeatedly checked and found to contain $35 \mathrm{mg}$. nitrogen per gram of granules; the enzyme activity was also checked several times and found to be fully potent. The diet was kept constant throughout each balance and was the type of diet in amount and variation to which the child was accustomed. The fat and nitrogen content of the diet was calculated by the hospital dietitian from the tables devised by McCance and Widdowson (1940). All food was weighed The fat and nitrogen content of the diet was then checked by chemical estimation of these constituents in a whole day's food.

The fat and nitrogen balances were carried out concurrently, the fat for a minimum of eight days and the nitrogen for two consecutive five-day periods. Daily faecal fat estimations were carried out and the result expressed as the percentage absorption for each 24-hour period. To correct for any lag in intestinal absorption the three-day sliding mean of these percentages was calculated and, from these figures, the average percentage absorption for the whole eight days. The nitrogen output was estimated as a total for each five-day period, the urine being pooled and volumetric samples taken of the homogenized faeces which were then also pooled. Carmine was used to mark the beginning and end of each balance period. An average was calculated for the two five-day periods.

The children were cared for in one special metabolic ward and led a normally active life, attending hospital school and having outings. Several days were allowed after admission for the child to settle down in the ward 
EFFECT OF PANCREATIN THERAPY ON FIBROC YSTIC DISEASE OF PANCREAS 425

TABLE 1

FAT BALANCES AND AVERAGE PERCENTAGE FAT ABSORPTION

\begin{tabular}{|c|c|c|c|c|c|c|c|c|c|c|c|c|c|c|c|}
\hline Case Number & $\cdots$ & . & $\cdots$ & 1 & 2 & 3 & 4 & 5 & 6 & 7 & 8 & 9 & 10 & 12 & \\
\hline Age in years & $\cdots$ & $\cdots$ & $\cdots$ & 8 & $5 \mathrm{I}^{7}$ & $8 \frac{1}{2}$ & $6 \frac{11}{12}$ & $7 \frac{2}{12}$ & $8 \frac{11}{1} \frac{1}{2}$ & $7 \frac{1}{2}$ & $4 \frac{7}{12}$ & $5 \frac{1}{2}$ & $6 \frac{1}{2}$ & 10 & \\
\hline Sex & $\ldots$ & . & $\ldots$ & $\mathbf{M}$ & $\mathbf{F}$ & $\mathbf{F}$ & $\mathbf{M}$ & $\mathbf{M}$ & $\mathbf{F}$ & $\mathbf{F}$ & $\mathbf{F}$ & $\mathbf{M}$ & $\mathbf{M}$ & $\mathbf{M}$ & \\
\hline \multicolumn{2}{|c|}{ Average fat intake (g.) } & . & $\cdots$ & $79 \cdot 6$ & $62 \cdot 2$ & $61 \cdot 1$ & $70 \cdot 2$ & $69 \cdot 5$ & $72 \cdot 4$ & $65 \cdot 1$ & 63.9 & 56.4 & $67 \cdot 9$ & $89 \cdot 7$ & \\
\hline & & $\begin{array}{l}\text { Pancreatin } \\
\text { (g. q.d.s.) }\end{array}$ & & & & & & & & & & & & & $\begin{array}{l}\text { Average for } \\
\text { All Cases }\end{array}$ \\
\hline \multirow{3}{*}{$\begin{array}{c}\text { Average } \% \text { Fat } \\
\text { Absorption }\end{array}$} & & 0 & & 40 & 57 & 37 & 54 & 65 & 37 & $42^{*}$ & 69 & 43 & 31 & 32 & 46 \\
\hline & & 5 & & $52^{*}$ & 61 & 56 & 71 & 78 & 65 & $69^{*}$ & 88 & 65 & 57 & $58^{*}$ & 67 \\
\hline & & 15 & & 62 & $69 *$ & 66 & 78 & $74^{*}$ & $67^{*}$ & 75 & $86^{*}$ & 76 & 55 & 69 & 71 \\
\hline
\end{tabular}

* Indicates some disturbance of health during balance.

and become stabilized on the measured diet and there were also rest periods between balances during which time they were stabilized on the different amounts of pancreatin. In addition, three chylomicron curves were carried out on each child, without pancreatin and with 5 and $15 \mathrm{~g}$. given with the fatty meal.

Clinical observations were made on the children during the balances and any disturbances in health noted. They were weighed every third day.

\section{Discussion of Results}

Twelve children were studied. The results of the fat and nitrogen balances on one of these (Case 11, L.B.) will be discussed separately. The other 11 are discussed as a group.

Fat Absorption. The results of the fat balances showed that the fat absorption was considerably increased by the addition to the diet of $5 \mathrm{~g}$. pancreatin four times a day before each meal, whilst $15 \mathrm{~g}$. in most cases caused a further but smaller increase. These results were so clear that the figures were not analysed further.

Disturbances in health were quickly reflected in the fat balances. For example, Case 12 developed an upper respiratory infection on the eighth day of the 5-g. balance. A tachycardia had been noted on the seventh day, but the fat absorption on the sixth day had already dropped to $39 \%$ and the three-day sliding mean showed the following result: $55 \%$, $79 \%, 86 \%, 62 \%, 31 \%, 37 \%$. The decrease in fat absorption occurred in the absence of any antibiotics.

Nitrogen Absorption. The figures for the average faecal excretion of nitrogen (Table 2) show that this dropped to just under a half with the addition of $5 \mathrm{~g}$. pancreatin to the diet. No further significant diminution in the faecal nitrogen excretion occurred when $15 \mathrm{~g}$. were given.
TABLE 2

NITROGEN BALANCES

\begin{tabular}{c|c|c}
\hline $\begin{array}{c}\text { Pancreatin } \\
\text { (g. q.d.s.) }\end{array}$ & $\begin{array}{c}\text { Mean Output of } \\
\text { Nitrogen in Faeces (g.) }\end{array}$ & $\begin{array}{c}\text { Standard Error } \\
\text { of Mean }\end{array}$ \\
\hline 0 & $\begin{array}{c}23 \cdot 10 \\
10 \cdot 78\end{array}$ \\
$10 \cdot 27$ & $1 \cdot 24$ \\
15 & $1 \cdot 02$ \\
& $1 \cdot 26$ \\
\hline Mean difference without pancreatin and with 5 g. q.d.s. $-12 \cdot 32 \mathrm{~g}$. \\
Standard error 1.07 (P<0.001). \\
\hline Mean difference with pancreatin 5 g. q.d.s. and 15 g. q.d.s. $-0.51 \mathrm{~g}$. \\
Standard error 1.86 (P>0.7).
\end{tabular}

The nitrogen retention (Table 3) was considerably increased by the administration of $5 \mathrm{~g}$. pancreatin, and even more when the larger dose of $15 \mathrm{~g}$. was given. The average nitrogen retention was in fact more than six times as great with the larger dose of pancreatin as with the smaller dose. This increased retention could have been due either to increased intake of nitrogen or to diminished loss in the stools. As the faecal loss of nitrogen dropped to just under half whether 5 or $15 \mathrm{~g}$. were given, the increase in nitrogen retention could not entirely have been due to pancreatic enzyme activity. On the other hand, the addition of the maximum dosage of pancreatin of $60 \mathrm{~g}$. daily contributed to an approximately $25 \%$ increase in the average daily intake of protein, which was $55 \cdot 3 \mathrm{~g}$.

TABLE 3

NITROGEN BALANCES

\begin{tabular}{c|c|c}
\hline $\begin{array}{c}\text { Pancreatin } \\
\text { (g. q.d.s.) }\end{array}$ & $\begin{array}{c}\text { Mean Balance of } \\
\text { Nitrogen (g.) }\end{array}$ & $\begin{array}{c}\text { Standard Error } \\
\text { of Mean }\end{array}$ \\
\hline 0 & $\begin{array}{c}3.75 \\
+1.61\end{array}$ \\
15 & +10.77 & 1.3 \\
& 1.44 \\
\end{tabular}

Mean difference without pancreatin and with 5 g. q.d.s. $-5 \cdot 36$. g. Standard error $2 \cdot 11(\mathrm{P}>0 \cdot 02)$.

Mean difference with pancreatin $5 \mathrm{~g}$. q.d.s. and $15 \mathrm{~g}$. q.d.s. $-9 \cdot 16 \mathrm{~g}$ Standard error $1.62(P<0.001)$. 
The effect of ill health on nitrogen retention was clearly seen even in those cases where the disturbance was slight. For example, Case 7 had a mild attack of abdominal pain with a temperature of $99.4^{\circ} \mathrm{F}$. on the ninth day of the balance study without pancreatin. When the child recovered, the balance with $15 \mathrm{~g}$. four times daily was begun and this showed a low nitrogen retention for the first five days. The balance was then continued for two further five-day periods and showed increasing nitrogen retention.

Chylomicron Curves. These showed slight but definite improvement when pancreatin was given (Fig. 1) though even so the curves obtained did not approach normal.

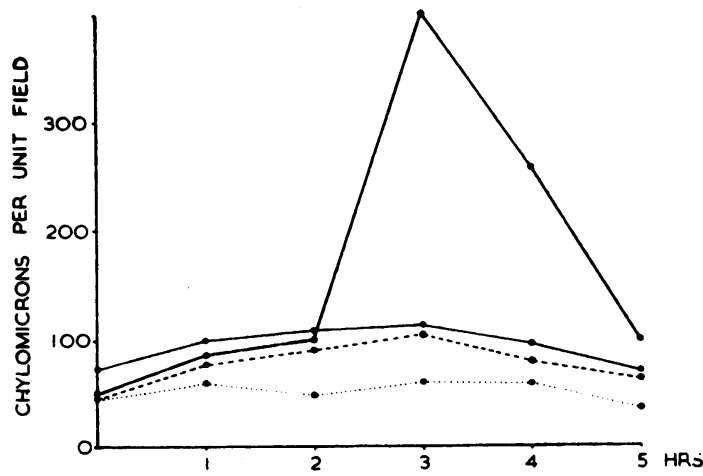

Fig. 1.-Curves showing average chylomicron counts.

$\begin{array}{ll}\ldots \ldots \ldots & \text { Without pancreatin. } \\ & \text { With } 5 \mathrm{~g} \text {. of pancreatin. } \\ & \text { With } 15 \mathrm{~g} \text {. of pancreatin }\end{array}$

Normal curve.

Weight. The children showed marked gain in weight when the largest amount of pancreatin was given, corresponding to the increased nitrogen retention and improved fat absorption (Fig. 2). The weight tended to remain more or less stationary when $5 \mathrm{~g}$. of pancreatin were given and to fall when pancreatin was withheld. It is evident that although supposed to be receiving an ample high-protein diet, most of these children probably had too low a protein intake.

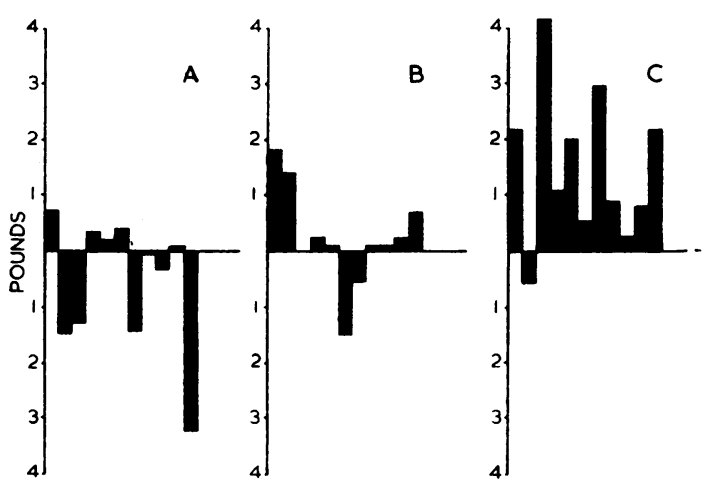

FIG. 2.-Weight gain or loss of each child during investigation.

A. Without pancreatin.

B. With $5 \mathrm{~g}$. of pancreatin four times daily.

C. With $15 \mathrm{~g}$. of pancreatin four times daily.

Faeces. As was to be expected, these children passed enormous stools with undigested food and fat in them, but it was found that the volume of the stools dropped to about a third on $15 \mathrm{~g}$. pancreatin four times daily and, though still unpleasant in smell, were more formed in character.

General Health. Except where indicated, the children all remained in good general health. Cases $1,2,7,8$ and 12 had mild upper respiratory infections, Case 5 vomited during the $15 \mathrm{~g}$. balance, Case 6 had loose stools and Case 7 abdominal pain and slight fever. It was observed that a few of the children complained of abdominal discomfort when the large dose of pancreatin was given.

CASE 11. This girl, aged 7 years 9 months, was of special interest clinically because she appeared to be a case of fibrocystic disease of the pancreas with fairly severe involvement of the respiratory tract. An older sister has proven fibrocystic disease with severe pulmonary involvement. The child studied, however, was found to have a normal content of amylase in the duodenal juice, and tryptic digestion of $2 \mathrm{ml}$. of $7 \cdot 5 \%$ gelatin to a dilution of 1 in 400 , which is within normal limits, although only 17 units of lipase were present per $100 \mathrm{ml}$. juice (normal 38-100 units). The results of the metabolic balances are given in Table 4 . These results show that her fat absorption was unaffected by pancreatic

TABLE 4

RESULTS OF METABOLIC BALANCES IN CASE 11

\begin{tabular}{|c|c|c|c|c|c|c|c|c|c|c|}
\hline \multirow{2}{*}{ Pancreatin } & \multirow{2}{*}{$\begin{array}{c}\text { Intake } \\
\text { Nitrogen } \\
\text { (g.) }\end{array}$} & \multicolumn{3}{|c|}{ Output Nitrogen (g.) } & \multirow{2}{*}{$\begin{array}{c}\text { Intake } \\
\text { Nitrogen } \\
\text { (g.) }\end{array}$} & \multicolumn{3}{|c|}{ Output Nitrogen (g.) } & \multirow{2}{*}{$\begin{array}{l}\% \text { Fat } \\
\text { Absorp- } \\
\text { tion }\end{array}$} & \multirow{2}{*}{$\begin{array}{l}\text { Weight Gain } \\
\text { or Loss } \\
\text { (oz.) }\end{array}$} \\
\hline & & Urine & Faeces & Balance & & Urine & Faeces & Balance & & \\
\hline $\begin{array}{r}0 \\
5 \\
15\end{array}$ & $\begin{array}{l}43 \cdot 7 \\
47 \cdot 2 \\
54 \cdot 2\end{array}$ & $\begin{array}{l}36 \cdot 1 \\
38 \cdot 5 \\
32 \cdot 0\end{array}$ & $\begin{array}{r}7 \cdot 3 \\
10 \cdot 2 \\
10 \cdot 5\end{array}$ & $\begin{array}{r}+0 \cdot 3 \\
-1 \cdot 5 \\
+11 \cdot 7\end{array}$ & $\begin{array}{l}43 \cdot 7 \\
47 \cdot 2 \\
54 \cdot 2\end{array}$ & $\begin{array}{l}29 \cdot 3 \\
33 \cdot 9 \\
39 \cdot 1\end{array}$ & $\begin{array}{l}9 \cdot 9 \\
7 \cdot 4 \\
8 \cdot 1\end{array}$ & $\begin{array}{r}+4.5 \\
+5.9 \\
+7.0\end{array}$ & $\begin{array}{l}88 \\
84 \\
84\end{array}$ & $\begin{array}{r}-4 \\
+14 \\
+10\end{array}$ \\
\hline
\end{tabular}


therapy, but her nitrogen retention was improved and she gained $24 \mathrm{oz}$. in weight when given pancreatin.

In this case there was very little difference in the faecal nitrogen in the three sets of balances and the improved nitrogen retention must have been due to the utilization of the protein of the pancreatin as a food.

\section{Conclusion}

It was concluded from these studies that the absorption and utilization of fat and protein in children with fibrocystic disease of the pancreas was improved by pancreatic therapy as shown by gain in weight, positive nitrogen balances and increased fat absorption. Five grams of pancreatin with each meal is probably the largest dose required, any increase in this amount resulting in very little improvement in enzymatic activity. Apparent clinical improvement on a larger dose, as shown by increase in body weight, is due to the increased nitrogen intake obtained from the pancreatin. Intercurrent illnesses diminish absorption of fat and nitrogen even if large doses of pancreatin are being given.

We would like to acknowledge the spirit shown by the children and their parents in agreeing to a prolonged stay in hospital for the sake of this work. We also wish to thank Miss Dilliston and her staff from the diet kitchen for their help, and Dr. Cedric Carter for his assistance in the statistical analysis of the results. The work was made possible by grants from Messrs. Cow and Gate and the Research Committee of The Hospital for Sick Children, to whom our thanks are due.

\section{REFERENCES}

Bodian, M. (1952). Fibrocystic Disease of the Pancreas, p. 40.

May, C. D. (1954). Cystic Fibrosis of the Pancreas in Infants and Children. (Amer. Lect. Ser., no. 234.) Springfield, Illinois. McCance, R. A. and Widdowson, E. M. (1940). Spec. Rep. Ser. med. Res. Coun., Lond., No. 235.

Norman, A. P. (1954). In Recent Advances in Paediatrics, ed. D. Gairdner, p. 256 . London.

Rapoport, M. (1954), In Textbook of Pediatrics, p. 748, 6th ed. ed. Nelson, W. E. Philadelphia. 